\title{
Towards a Single and Comprehensive Notion of 'Civilian Population' in Crimes against Humanity
}

\author{
Rosa Ana Alija Fernández \\ Senior Lecturer of Public International Law and International Human Rights \\ Law, Department of Criminal Law and Criminology and Public International \\ Law, Universitat de Barcelona, Barcelona, Spain \\ ralija@ub.edu

Jaume Saura Estapà

Professor of Public International Law and International Human Rights Law, Department of Criminal Law and Criminology and Public International Law, Universitat de Barcelona, Barcelona, Spain jsaura@ub.edu.

\begin{abstract}
Although an essential element of the definition of crimes against humanity is that a civilian population be targeted, there is no agreement on what 'civilian population' means in this context. The notion has been given different meanings depending on whether the crimes are committed in times of conflict or peacetime. In times of conflict, preference is given to a broad approach based on international humanitarian law. More problematic is the attribution of a specific content to the notion in peacetime, where even discrimination has been suggested as a defining criterion. In this article we contend that a single notion of 'civilian population' in crimes against humanity applicable in every circumstance is needed. Hence, we suggest determining the civilian population on the basis of the rules on State responsibility in international human rights law and general international law in order to exclude those endowed with public authority from the civilian population.

* Jaume Saura Estapà is a member of the TransJus Research Institute (UB) and Deputy General to the Síndic de Greuges (Catalan Ombudsman). This paper was written in the framework of the research project La exigibilidad jurídica internacional de los derechos económicos, sociales y culturales en períodos de crisis" (Spanish Ministry of Innovation and Science, DER2012-30652).
\end{abstract}




\section{Keywords}

crimes against humanity - civilian population - international humanitarian law international criminal law

\section{$1 \quad$ Introduction}

Certain abhorrent acts that breach fundamental human rights become crimes against humanity when committed as part of a widespread or systematic attack directed against any civilian population pursuant to a State or organizational policy, with knowledge of such attack by the author. This specific context provides the general chapeau of the category and makes such criminal acts a threat to international peace and security and therefore of such gravity that they must not go unpunished, as the Preamble of the Statute of the International Criminal Court (ICC) reminds. Under customary international law - also reflected in Article 7 ICC Statute - the general chapeau requirements would be the following: (i) there must be an attack; (ii) the acts of the perpetrator must be part of the attack; (iii) the attack must be directed against any civilian population; (iv) the attack must be widespread or systematic; and (v) the perpetrator must know that his acts constitute part of a pattern of widespread or systematic crimes directed against a civilian population and know that his acts fit into such a pattern. ${ }^{1}$

An essential element of the definition of crimes against humanity is therefore that the attack targets any civilian population. Even so, there exists no agreement on what should be understood by 'any civilian population' and who should be included in it. The original configuration of crimes against humanity in Article 6(c) of the 1945 Charter of the International Military Tribunal of Nuremberg (IMTN) connecting them to war crimes and crimes against peace therefore to a situation of international armed conflict - leads to an initial answer: it should be interpreted in light of International humanitarian law (I HL). However, the conceptual autonomy reached by crimes against humanity in customary international law since $1945^{2}$ asks for a specific meaning within this

1 Prosecutor v. Kunarac et al., 12 June 2002, International Criminal Tribunal for the former Yugoslavia ['ICTY'], Appeal Judgment, IT-96-23 \& IT-96-23/1-A, para. 65; The Prosecutor v. Germain Katanga, 7 March 2014, ICC, Judgment pursuant to Article 74 of the Statute, ICC-01/ 04-01/07, paras. 1097-1099.

2 The nexus with an armed conflict was already suppressed in Article II(1)(c) of Control Council Law N ${ }^{\circ}$. 10. Although Article 5 of the Statute of the ICTY re-introduced it, the Tribunal 
criminal category. Although assuming that IHL should be the primary reference to define the term, international tribunals and commentators have since tended to broaden its scope as an element of crimes against humanity.

The ICc Statute sheds no light on the scope of this term, as the drafters consciously left its exact meaning undefined. According to Lee, '[m] ost delegations quickly agreed that this was too complex a subject and evolving area in the law, better left to resolution in case-law.' ${ }^{3}$ Consistently, no explanation of the meaning of 'civilian population' in Article 7 ICC Statute is offered in the ICC Elements of Crimes either. ${ }^{4}$ References to civilian population in war crimes included in Article 8 ICC Statute remains equally undefined. ${ }^{5}$ Adding further confusion, the ICC case-law is not congruous, as a twofold criterion is currently used to determine the civilian nature of a population.

The meaning of the term 'civilian population' is not self-evident, and the lack of a uniform definition for it is quite undesirable in a field such as the application of criminal rules, that require a high degree of certainty and precision in order to fulfil the principle of legality. Today, it seems clear that the term does not bear the same meaning in war crimes and in crimes against humanity, as crimes against humanity can be committed both in times of armed conflict and in peacetime. So, there is an evident need to reassess the scope given to the term so far, in order to provide it with a single and comprehensive meaning. The civilian population needs to be determined in a way suitable to any possible scenario where these crimes are committed. As we shall see, the ICc gives the term a different content within the category of crimes against humanity, depending on whether they are committed in times of war or peace: in armed conflicts, 'civilian population' includes those who are not members of armed forces and other legitimate combatants, while in peacetime it is equated to a distinguishable group. Such duality makes no sense and should be urgently overcome.

In this article, we contend none of the approaches currently provided to determine the civilian population in crimes against humanity are fully

stated that 'an examination of customary international law indicates that as customary rules on crimes against humanity gradually crystallised after 1945, the link between crimes against humanity and war crimes disappeared' (Prosecutor v. Kupreškić et al., 14 January 2000, ICTY, Trial Judgment, IT-95-16-T, para. 577).

3 Roy S. Lee (ed.), The International Criminal Court: Elements of Crimes and Rules of Evidence (Transnational Publishers, New York, 2001), p. 78.

4 ICC, Elements of Crimes (ICC-ASP/1/3, Part II.B), Introduction to Article 7, p. 5.

5 See e.g., the elements of the crime in Article 8(2)(b)(i) (ibid., p. 130). The Elements of Crimes do explain instead what civilian objects are ('that is, objects which are not military objectives', according to the elements of the crime in Article 8(2)(b)(ii), in ibid.). 
satisfactory, and further criteria need to be explored. For a better understanding of the evolution of the scope given to the civilian population as an element of the general chapeau of crimes against humanity and its persisting shortcomings, we will first focus on its delimitation in I HL (Section 2). We then move to the double standard used to determine it in crimes against humanity: the broadening of the IHL approach operated by international criminal tribunals in order to adapt the element to the particular features of crimes against humanity committed in times of conflict, followed by the different criteria offered by the international case-law to determine the civilian population in times of peace (Section 3). With this general outlook in mind, we will put forward an alternative criterion inspired by international human rights law (Section 4), to end up with some conclusions (Section 5).

\section{2 \\ The Distinction between Combatants and Civilians in International Humanitarian Law}

One, if not the most important, rule of International humanitarian law is the principle of distinction between combatants and civilians. Not surprisingly, the impressive compilation of customary IHL produced by the ICRC ${ }^{6}$ establishes, as Rule \#1, that ' $[\mathrm{t}]$ he parties to the conflict must at all times distinguish between civilians and combatants. Attacks may only be directed against combatants. Attacks must not be directed against civilians'. ${ }^{7}$

This crucial principle begs the question of identifying both categories of individuals, a distinction that international humanitarian law does not perform directly. The notion of 'combatant' is found essentially in the Third Geneva Convention, as only lawful combatants can eventually become, when captured, prisoners of war ('POW'). Instead, 'civilians' are not defined, although it can be derived that theirs is a negative notion, as reflected by Rule \# 5 of the customary norms of the ICRC: 'Civilians are persons who are not members of the armed forces. The civilian population comprises all persons who are civilians'. ${ }^{8}$

6 Jean-Marie Henckaerts and Louise Doswald-Beck, Customary International Humanitarian Law, vol. 1 (Cambridge University Press/International Committee of the Red Cross, Cambridge, 2004, repr. 2009), p. 3.

7 As a matter of fact, the compilation dedicates its first six 'rules' to the principle of distinction between civilians and combatants, and the following four rules to the distinction between military objectives and civilian property (emphasis added).

8 See Henckaerts and Doswald-Beck, supra note 6, p. 17. 
In the context of an international armed conflict, individuals are basical- 113 ly either combatants (Section 2.1) or civilians (Section 2.2). Among civilians, 114 some have a differentiated status (e.g., journalists and humanitarian person- 115 nel), just as there are unique situations among the former group (e.g., medical 116 and religious personnel that belong to regular armies but are not considered 117 combatants). Combatants hors de combat become something else ('wounded', 118 'prisoner of war'...) that derives from the status as combatant. Finally, non- 119 international armed conflicts (NIAC) demand the same distinction between 120 combatants and civilians as the international ones, but in their context the 121 lack of certainty about who is a civilian remains quite high (Section 2.3). 122 to Become Pows

Within the rationale of international humanitarian law, a combatant is not per se, a criminal, nor has any responsibility over the crimes committed by his government, i.e. an illegal use of armed force. In an international armed conflict, a combatant that falls in the hands of enemy forces can be retained with one main purpose: to impede him from re-joining his armed forces. Additionally, and with important limitations, international humanitarian law allows the Detaining Power to obtain from him two valued goods: information and labour. But in no case he is or should be punished for having combated. ${ }^{9}$ This explains most of the provisions of the Third Geneva Convention (GCIII) in relation with the conditions of detention and with the rights and duties attributed to the Pow and his captors, including the fact that, once the armed conflict is over, the pow must be freed and repatriated immediately. This is also why the Convention devotes quite an effort to determine who is a legitimate combatant.

The GCIII defines a POW as any combatant that has been captured by enemy forces. Combatant is, thus, a category defined with a single purpose: the recognition of the Pow status.

Combatants are, primarily but not only, any member of the regular armed forces of a State and assimilated bodies, even if they belong to governments not recognized by the Detaining Power (paragraphs 1 and 3 of Article 4 GCIII). ${ }^{10}$

9 John Hickman, 'What is a Prisoner of War For?', 36(2) Scientia Militaria: South African Journal of Military Studies (2008) 1-17.

10 On lawful and unlawful combatants, see, among many others: Mary E. O'Connell, 'Combatants and the Combat Zone', 43 University of Richmond Law Review (2008-2009) 845 , and Knut Dörmann, 'The legal situation of "unlawful/unprivileged combatants", 85(489) International Revue of the Red Cross (2003) 45. 
Also, other categories of individuals in arms are considered lawful combatants in Article 4(2), as long as they meet specific requirements that are implied (but not formally required) for regular armed forces. Thus:

Members of other militias and members of other volunteer corps, including those of organized resistance movements, belonging to a Party to the conflict and operating in or outside their own territory, even if this territory is occupied, provided that such militias or volunteer corps, including such organized resistance movements, fulfil the following conditions:

(a) that of being commanded by a person responsible for his subordinates;

(b) that of having a fixed distinctive sign recognizable at a distance;

(c) that of carrying arms openly;

(d) that of conducting their operations in accordance with the laws and customs of war.

Even groups of civilians that spontaneously take up arms 'to resist the invading forces, without having had time to form themselves into regular armed units, provided they carry arms openly and respect the laws and customs of war' (thus not meeting the first two requirements mentioned in paragraph 4) are considered combatants by Article 4(6) GCIII.

Thus, there is a strong presumption that a person in arms, in the context of an international armed conflict, is a legitimate combatant. Even more so if we consider what Article 5 GCIII provides when there are 'doubts' on the condition of combatant or non-combatant of individuals in arms detained in an international armed conflict:

Should any doubt arise as to whether persons, having committed a belligerent act and having fallen into the hands of the enemy, belong to any of the categories enumerated in Article 4, such persons shall enjoy the protection of the present Convention until such time as their status has been determined by a competent tribunal.11

Whether a 'doubt' exists or not does not depend on the spirits of the Detaining Power. A doubt exists when it 'appears' that the individual may be a combatant, but also, very importantly, as long as the individual himself or his country claims such status. Article 45(1) Additional Protocol I to the Geneva Conventions (API) is clear in this respect and develops Article 5 GCIII in the following way:

11 Emphasis added. 
A person who takes part in hostilities and falls into the power of an ad- 179 verse Party shall be presumed to be a prisoner of war, and therefore shall 180 be protected by the Third Convention, if he claims the status of prison- 181 er of war, or if he appears to be entitled to such status, or if the Party on 182 which he depends claims such status on his behalf by notification to the 183 detaining Power or to the Protecting Power. Should any doubt arise as to 184 whether any such person is entitled to the status of prisoner of war, he 185 shall continue to have such status and, therefore, to be protected by the 186 Third Convention and this Protocol until such time as his status has been $\quad 187$ determined by a competent tribunal. ${ }^{12}$

It is enough for a detained person or his country to claim his condition as a pow in order for the Detaining Power to presume he was a legitimate combatant. And such an allegation can be expressed at any time, even when he is judged for crimes related to the conflict, in which case the competent tribunals must give priority to the claim - Article 45(2) API.

Civilians 'are to be protected from the dangers arising from military operations and are not to be the object of an attack'. ${ }^{13}$ Other protective measures in favour of the 'civilian population' include the prohibition of attacks to objects indispensable for their survival as well as their forced displacement. These measures are addressed towards the civilian population of the other belligerent party, i.e. enemy civilians. It is interesting to mention that the Geneva regime contains a few duties concerning each party's own civilian population (e.g., they cannot transfer it to an occupied territory ${ }^{14}$ and must disseminate international humanitarian law among it), ${ }^{15}$ none of which is focused on their protection.

As seen earlier, a civilian is anyone who is 'not a member of the armed forces. ${ }^{16}$ Article 50 API defines a civilian in a negative fashion as '[a]ny person who does not belong to one of the categories of persons referred to in Article

\footnotetext{
12 Emphasis added.

13 Kenneth W. Watkin, Combatants, Unprivileged Belligerents and Conflicts in the 21st Century, International Humanitarian Law Research Initiative Seminar Paper (2003), p. 2, <www .hpcrresearch.org/sites/default/files/publications/Session2.pdf>, 23 September 2016.

14 See Article 49 in fine of the Fourth Geneva Convention.

15 Article 83 API and Article 19 Additional Protocol II (which binds the Government and armed opposition groups).

16 See Henckaerts and Doswald-Beck, supra note 6, p. 17.
} 
$4 \mathrm{~A}(1),(2),(3)$ and $(6)$ of the Third Convention and in Article 43 of this Protocol'. Civilians are, thus, not only alien to the 'armed forces', but more broadly, non-combatants. ${ }^{17}$

Article $5^{0}$ further clarifies that 'the civilian population comprises all persons who are civilians' and that 'the presence within the civilian population of individuals who do not come within the definition of civilians does not deprive the population of its civilian character'. The most striking provision in this article is that 'in case of doubt whether a person is a civilian, that person shall be considered to be a civilian'. This potentially collides with the above mentioned presumption of pow status 'in case of doubt' and must be thus understood in the context of the 'protection' of civilians against armed attacks and not necessarily in the context of their detention for taking up arms. ${ }^{18}$

In this respect, civilians 'enjoy this protection until such time as they take a direct part in hostilities.19 Nonetheless, a civilian in arms is still a civilian, although he is no longer protected from direct attacks. From the point of view of his treatment as a detained individual, any person to whom the GCIII is not applicable (either because he is a pure civilian or because he has taken up arms in a fashion not contemplated in any of the above provisions) is under the protection of the Fourth Geneva Convention (GCIV). Article 4 of this Convention as well as API clearly determine the absence of any lacuna in the treatment of individuals involved or affected by an international armed conflict with the widest possible definition of 'protected persons':

Persons protected by the Convention are those who at a given moment and in any manner whatsoever find themselves, in case of a conflict or occupation, in the hands of a Party to the conflict or Occupying Power of which they are not nationals. ${ }^{20}$

Besides, Part II of GCIV, entitled 'General Protection of Populations Against Certain Consequences of War', applies to 'the whole of the populations of the countries in conflict, without any adverse distinction based, in particular, on race, nationality, religion or political opinion' (Article 13, emphasis added).

\footnotetext{
17 In this respect, it is worth noting that the excluded paragraphs refer to civilian individuals and crews that accompany armed forces without being members thereof. These individuals enjoy Pow status without losing their civilian condition. In this respect, it is important to recall that the doubt mentioned in Article 4 GCIII refers to 'persons, having committed a belligerent act' (emphasis added).

19 Article 51 API. See Watkin, supra note 13, p. 2.

20 Emphasis added.
} 
Moreover, the third paragraph of the above mentioned Article 45(3) API es- 238 tablishes that: 239

Any person who has taken part in hostilities, who is not entitled to pris240 oner-of-war status and who does not benefit from more favourable treat- 241 ment in accordance with the Fourth Convention shall have the right at all 242 times to the protection of Article 75 of this Protocol. ${ }^{21}$

Thus, a civilian who takes part in hostilities does so illegally and can be punished for this reason by the Detaining Power, unlike what we have predicated earlier about combatants. But he remains a civilian. The Geneva regime does not give carte blanche to the Detaining Power. The 'illegitimate' or 'unprivileged' combatant is protected by Article 75 API. This provision forbids murder, torture, corporal punishments, mutilation and any form of degrading or humiliating treatment. It also establishes some minimum procedural guarantees of a due process. In this fashion, the Protocol is consistent and builds upon what Article 71 GCIV was already establishing: 'No sentence shall be pronounced by the competent courts of the Occupying Power except after a regular trial'.22

All civilians are non-combatants even if they take up arms, but they are not the only ones. A specific category of non-combatants consists of the medical and religious personnel that are members of the regular armed forces of a given State. This status protects them from enemy attacks, but again, only 'as long as they do not directly participate in hostilities'. ${ }^{23}$ Potentially, if they take 257 up arms, doctors and chaplains may also become illegitimate or unprivileged combatants and face similar consequences as civilians directly participating in hostilities.

\section{Emphasis added.}

22 This article and the ones following develop the idea of a fair trial in an armed conflict situation. Eventually, a civilian that has taken up arms against a foreign or occupying power may be criminally charged and sentenced to prison. In some cases (spies, grave acts of sabotage or international breaches causing the death of one or more people) he could be sentenced to death penalty (Article 68), but always within the framework of a fair trial and a humane treatment.

23 Henckaerts and Doswald-Beck, supra note 6, p. 13. Likewise, while in the power of the enemy, they shall not become pow although they shall be treated as such: 'They shall, however, receive as a minimum the benefits and protection of the present Convention' (Article 33 GCIII). 


\subsection{Combatants and Civilians in Non-international Armed Conflicts}

The different status between civilians and combatants is further blurred in the context of NIAC. In such conflicts, there is a lack of legitimacy to carry out hostilities at least on the side of the 'rebels'. They are not legitimate combatants and Pow status for those who fall in the hands of the enemy, in either side, does not exist. Surprisingly enough, States have abstained from providing any plausible definition of combatants also on the Governmental side:

it is overwhelmingly apparent that States have not made any clear commitment of the issue of government forces' status in NIAC to international Law. Considerations including lack of necessity, general reluctance to yield sovereignty over internal affairs and lack of consensus have all contributed to the NIAC legal void. ${ }^{24}$

In spite of the above, the principle of distinction is fully in force also in NIAC, for Article 13(2) of Additional Protocol II ('APII'), among others, 'prohibits making the civilian population as such, as well as individual civilians, the object of attack'. ${ }^{25}$ This prohibition 'necessarily implies that there must be other individuals falling outside this protection who are subject to a presumption of targetability'. ${ }^{26}$ In sum, in NIAC there are combatants and civilians, but it is hard to know who is who.

APII does not contain a definition of civilian or of civilian population, although there are numerous references to one and the other throughout the text. In fact, a provision stating that 'a civilian is anyone who is not a member of the armed forces or of an organized armed group' was dropped at the last moment during the 1977 Conference. ${ }^{27}$

We must thus resort to indirect references. Common Article 3 to the four Geneva Conventions applies to persons 'taking no active part in the hostilities', but this terminology is too broad as it includes what IHL considers (former) combatants in international armed conflicts: 'including members of armed forces who have laid down their arms and those placed 'hors de combat' by sickness, wounds, detention, or any other cause'. As we shall see, the ad hoc

24 Sean Watts, 'Present and Future Conceptions of the Status of Government Forces in Non-International Armed Conflict', 88 International Law Studies Series. Us Naval War College (2012) 153 .

25 Henckaerts and Doswald-Beck, supra note 6, p. 6. Emphasis added.

26 Geoffrey Corn and Chris Jenks, 'Two Sides of the Combatant Coin: Untangling Direct Participation in Hostilities from Belligerent Status in Non-International Armed Conflicts', 33(2) University of Pennsylvania Journal of International Law (2011-2012) 330. 
criminal tribunals have equated all these non-combatants to civilians in the 293 context of crimes against humanity. ${ }^{28}$

APII is applicable without discrimination to 'all persons affected by a [non-international] armed conflict'. ${ }^{29}$ This includes 'les personnes qui ne prennent pas - ou plus - aux hostilités ... ce sont celles qui doivent, au sens du Protocole, se conformer à certaines règles de comportement à l'égard de l'adversaire et de la population civile.' ${ }^{30}$ Thus, absolutely everyone is 'affected' by the NIAC, including the armed parties.

APII devotes a specific chapter to 'civilian population', where we find out that 'civilians' are immune from direct attack 'unless and for such time as they take a direct part in hostilities', ${ }^{31}$ but again, there is no clue as to how to identify these protected individuals.

Based on the above, some authors maintain that everyone is a civilian on the side of the rebels and all of them constitute 'civilian population' as long as, and for the time that, they do not take a direct part in hostilities. This would be consistent with the fact that, once detained, they will not enjoy Pow status (although they should be treated humanely and prosecuted fairly). As pinpointed by one commentator: 'opposition fighters captured in NIAC, no matter their appearances or conduct, are likely to be regarded as mere criminals, fully subject to the domestic penal regime of the territorial State.' ${ }^{32}$ It also makes sense within the widely prevalent contemporary non-international armed conflicts, which are unstructured. ${ }^{33}$

Nonetheless, this interpretation has raised numerous criticisms and is particularly shocking if we envision a 'classic' non-international armed conflict with organized rebels that essentially meet the requirements of belligerency. ${ }^{34}$

30 Comité International de la Croix-Rouge, Commentaire des Protocoles additionnels du 8 juin 1977 aux Conventions de Genève du 12 août 1949 (CICR, Genève, 1986), para. 4485, p. 1383.

$31 \quad$ Article 1 (3) APII.

32 Watts, supra note 24, p. 148.

33 Jacques Forster, "The 6oth anniversary of the Geneva Conventions and the 15oth anniversary of the idea of the Red Cross and Red Crescent Movement', in Marco Odello and Gian Luca Beruto (eds.), Non-State Actors and International humanitarian law. Organized Armed Groups: A Challenge for the 21st Century. 32nd Round Table on Current Issues of International humanitarian law, Sanremo, 11-13 September 2009 (FrancoAngeli, Milano, 2010), p. 233 .

34 Corn and Jenks, supra note 26, p. 331 : 'This interpretation is fatally flawed ... as it distorts the fundamental lines of authority and obligation historically associated with armed conflict'. 
belonging to armed forces 'or to the armed groups may be attacked at any time' (e.g., in their headquarters), unlike civilians in arms that can only be attacked when they actively participate in hostilities. ${ }^{35}$

The question remains open and the more recent ICRC Compilation acknowledges that 'practice is not clear as to whether members of armed opposition groups are civilians subject to Rule 6 on loss of protection from attack in case of direct participation or whether members of such groups are liable to attack as such.36 For our purposes, it becomes obvious that the notion of 'civilian population', which is of paramount importance to define war crimes, suffers a progressive blurring as we move from international to noninternational armed conflicts. This process of indeterminacy of the notion will further intensify as we consider crimes against humanity, particularly in times of peace.

\section{Any 'Civilian Population' as an Element of the General Chapeau of Crimes against Humanity: An Unsuitable Double Standard}

Although crimes against humanity can be committed both in times of armed conflict and in times of peace, the meaning given to the 'civilian population' element in this criminal category has been traditionally based on the IHL definition of the term. Admittedly, it has been later broadened - particularly as far as the civilian element is concerned - in order to provide it with a content of its own within crimes against humanity. As a result, civilian status is not only granted to non-combatants, but even to combatants (Section 3.1). Nonetheless, while this distinction can work in the context of an armed conflict, it becomes insufficient when crimes against humanity are committed in times of peace. This would explain the jurisprudential development of an alternative criterion based on discrimination that would apply to situations where no armed conflict can be verified (Section 3.2).

35 Comité International de la Croix-Rouge, supra note 30, para. 4789, p. 1475.

36 Henckaerts and Doswald-Beck, supra note 6, p. 19. It adds that 'most manuals define civilians negatively with respect to combatants and armed forces and are silent on the status of members of armed opposition groups'. A few years later, another research of the ICRC was a bit clearer: 'all persons who are not members of State armed forces or organized armed groups of a party to the conflict are civilians and, therefore, entitled to protection against direct attack unless and for such time as they take a direct part in hostilities' (Nils Melzer, Interpretative Guidance on the Notion of Direct Participation in Hostilities under International humanitarian law (ICRC, Geneva, 2009), p. 36). 
In search of a definition of 'civilian population' specific to crimes against a broad approach that emphasizes the collective nature of the target of the attack. Thus, the term population has been interpreted extensively, referring rather to the collective dimension of the crime and not so much to the status of the victims. ${ }^{37}$ Therefore, individual or isolated acts are excluded from the category of crimes against humanity. ${ }^{38}$ However, a plurality of victims in the same act is not a requirement in the general chapeau of the category, ${ }^{39}$ but that the context where crimes against humanity are committed involves a multiplicity of victims. This is implied both in the notion of attack ${ }^{40}$ (namely, a course of conduct involving the multiple commission of acts, as referred to in Article 7(1) ICC Statute $)^{41}$ against any civilian population and in that the attack is required to be widespread or systematic. The above does not mean that the commission of a specific crime against humanity results in many victims, a single inhuman act committed against one victim alone being a crime against humanity provided such act is connected to the attack. ${ }^{42}$ The number of victims caused by one act is then irrelevant for the purposes of describing it as a crime against humanity. What matters, instead, is that the attack is not directed against a

37 Prosecutor v.Jelisić, 14 December 1999, ICTY, Trial Judgment, IT-95-10-T, para. 54.

38 The Prosecutor v. Jean-Pierre Bemba Gombo, 21 March 2016, ICC, Judgment pursuant to Article 74 of the Statute, ICC-01/05-01/08, para. 152; Prosecutor v. Tadić, 7 May 1997, ICTY, Trial Judgment, IT-94-1-T, para. 644; Virginia Morris and Michael P. Scharf, An Insider's Guide to The International Criminal Tribunal for the Former Yugoslavia, vol. 1 (Transnational Publishers, Irvington-on-Hudson, 1995), p. 80.

39 Henri Meyrowitz, La répression par les tribunaux allemands des crimes contre l'humanité et de l'appartenance à une organisation criminelle, en application de la loi $n^{\circ} 10$ du Conseil de Contrôle Allié (Librairie Générale de Droit et de Jurisprudence R. Pichon et R. DurandAuzias, Paris, 1960), pp. 280-281; Gerhard Werle, Principles of International Criminal Law (T.M.C. Asser Press, The Hague, 2005), p. 221. But see Egon Schwelb, 'Crimes against Humanity', 23 British Yearbook of International Law (1946) 191; UnwCC, History of the United Nations War Crimes Commission and the Development of the Laws of War (H. M. Stationery Office, London, 1948), p. 193; Morris and Scharf, supra note 38, pp. 79-80; María Dolores Bollo Arocena, Derecho internacional penal. Estudio de los crímenes internacionales y de las técnicas para la represión (Universidad del País Vasco/Euskal Herriko Unibertsitatea, Bilbao, 2004), pp. 93-94.

40 Kai Ambos and Steffen Wirth, 'The Current Law of Crimes against Humanity. An analysis of UntaEt Regulation 15/2000', 13(1) Criminal Law Forum (2002) 22.

41 According to Article 7(2) ICC Statute.

42 Meyrowitz, supra note 39, p. 281. 
small and randomly selected number of individuals, ${ }^{43}$ but, on the contrary, against a collective target, hence resulting in many victims.

It should also be pinpointed that generic references to $a n y^{44}$ or $a^{45}$ civilian population included in treaty and case-law definitions of crimes against humanity have traditionally intended to eliminate any possible difference between people under the jurisdiction of the State as part of its population or of any other territory under its effective control. Crimes against humanity can be committed against people of the same nationality as the offender, against foreigners or stateless people. ${ }^{46}$ No part of the civilian population will therefore be excluded from the protection afforded by the prohibition to commit crimes against humanity. ${ }^{47}$ Likewise, these two references exclude that the object of the attack must be the entire civilian population. On the contrary, it will be sufficient that this attack is aimed against part of a civilian population within a certain geographical area. ${ }^{48}$ As remarked by the Supreme Court of Israel in the $P a l$ case,

'civilian population' is a broad term which includes also part of a civilian population (...). For instance, in a town where the majority of the population were Nazis, acts of extermination of a Polish minority would be acts of extermination of a civilian population. ${ }^{49}$

The key question, though, is the verification of the civilian nature of the population. To that end, international tribunals have usually followed IHL standards:

\footnotetext{
43 The Prosecutor v. Germain Katanga, supra note 1, para. 1105.

44 See generally Article 7 Icc Statute.

45 See e.g., Prosecutor v. Kunarac et al., supra note 1, para. 87-88.

46 Prosecutor v. Tadić, supra note 38, para. 635; International Law Commission, Report of the International Law Commission covering its 2nd Session, 5 June - 29 July 1950 (A/1316), para. 124; Schwelb, supra note 39, p. 206. In Fenrick's opinion, this reference makes irrelevant not only victims' nationality, but also their ethnicity (William J. Fenrick, 'The Crime against Humanity of Persecution in the Jurisprudence of the ICTY', XXXII Netherlands Yearbook of International Law (2001) 86).

47 Ambos and Wirth, supra note 40, p. 22.

48 Prosecutor v. Tadić, supra note 38, para. 644; Prosecutor v. Bagilishema, 7 June 2001, International Criminal Tribunal for Rwanda ['ICTR'], Trial Judgment, ICTR-95-1A-T; para. 80; Fenrick, supra note 46, p. 86; Werle, supra note 39, p. 223.

49 Pal v. Attorney-General, 6 June 1952, Supreme Court of Israel sitting as the Court of Criminal Appeals, in 18 International Law Reports (1952) 542. Civilians confined in a detention center keeping them apart from the rest of the population are also part of the civilian population (Attorney-General v. Tarnek, 14 December 1951, Tel Aviv District Court, in ibid., p. 540).
} 
the civilian population comprises all persons who are civilians as opposed to members of the armed forces and other legitimate combatants, thus relying on the broader distinction between combatants and non-combatants set forth in Article 50(1) API. ${ }^{50}$ As the ICC Trial Chamber II expressed in Katanga:

The expression 'civilian population' denotes civilians as opposed to 'members of armed forces and other legitimate combatants'. As such, the Chamber endorses the definition of 'civilian' provided by article 50(1) of Additional Protocol I and that of 'civilian population' provided by article 5o(2) of Protocol I, namely '[ $\mathrm{t}$ ] he civilian population comprises all persons who are civilians. ${ }^{51}$

Also in line with Article $5^{0}$ API, it is enough for the population targeted by the attack to be mainly civilian, what is specially significant in the event of an armed conflict, given that in such case the existence of combatants within the population does not change in essence its civilian nature. ${ }^{52}$ By the same token, a person shall be considered to be a civilian for as long as there is a doubt as to his or her status. ${ }^{53}$ In this respect, as the Commission of Experts established by virtue of resolution 780 (1994) of the Security Council put it,

it seems obvious that article 5 [of the Statute of the International Crimi403 nal Tribunal for the former Yugoslavia ('ICTY'), setting jurisdiction over crimes against humanity] applies first and foremost to civilians, meaning people who are not combatants. This, however, should not lead to any quick conclusions concerning people who at one particular point in time did bear arms. (...) Information of the overall circumstances is relevant for the interpretation of the provision in a spirit consistent with its purpose. ${ }^{54}$

50 See supra Section 2.2.

51 The Prosecutor v. Germain Katanga, supra note 1, para. 1102. See also Prosecutor v. Kunarac et al., 22 February 2001, ICTY, Trial Judgment, Iт-96-23 \& IT-96-23/1-T, para. 425.

52 The Prosecutor v.Jean-Pierre Bemba Gombo, supra note 38, para. 153; Prosecutor v. Kupreškić et al., supra note 2, para. 549; Prosecutor v. Tadić, supra note 38, para. 638; Prosecutor v. Kunarac et al., supra note 51 , para. 425 .

53 Prosecutor v. Kunarac et al., supra note 51, para. 426.

54 Security Council, Letter dated 94/05/24 from the Secretary-General addressed to the President of the Security Council (s/1994/674), Annex: 'Final Report of the Commission of Experts established pursuant to Security Council Resolution 780 (1992)', para. 78 (emphasis added). 
This trend in favour of a broad approach is also observed in case-law. In fact, in the trial judgment issued in the Blaskic case, the ICTY unqualifiedly puts civilians on the same level as those protected by common article 3 of the four Geneva Conventions $1949 .{ }^{55}$ The resulting criteria is to include in the same category of civilians people not taking active part in the hostilities together with those members of the armed forces who dropped weapons and those left out of combat. ${ }^{56}$ Besides, people generally who for one reason or another are not directly involved in fighting will be deemed civilians. ${ }^{57}$ Ultimately, 'the specific situation of the victim at the moment the crimes were committed, rather than his status, must be taken into account in determining his standing as a civilian'.58 In fact, the Appeals Chamber of the ICTY has held that it is not a requirement of crimes against humanity that individual victims are strictly civilians. ${ }^{59}$ Likewise, there is no reason to exclude from the notion of civilian those involved in resistance movements as they can also be victims of crimes against humanity. 60

Commentators pinpoint in this regard that in order to determine the civilian status of a person in the sense required by crimes against humanity, it is

55 Prosecutor v. Blaskić, 3 March 2000, ICTY, Trial Judgment, IT-95-14-T, para. 209.

56 See Prosecutor v. Milan Martić, 8 October 2008, ICTY, Appeal Judgment, IT-95-11-A, para. 311; Prosecutor v. Mrkšić et al., 5 May 2009, ICTY, Appeal Judgment, IT-95-13/1-A, para. 29; Prosecutor v. Galić, 5 December 2003, ICTY, Trial Judgment, IT-98-29-T, para. 143; Prosecutor v. Akayesu, 2 September 1998, ICTR, Trial Judgment, ICTR-96-4-T, para. 582. Cf. Pilz case, where the Special Court of Cassation of Holland considered that the acts of a German military doctor preventing a Dutch soldier from having medical attention and ordering, or at least permitting, a subordinate to shoot him did not amount to a crime against humanity, among other reasons because the victim was no longer part of the civilian population of the occupied territory (In re Pilz, 5 July 1950, Special Court of Cassation of Holland, in 17 International Law Reports (1950) 392).

57 Prosecutor v. Blaskić, supra note 55, para. 209.

58 Ibid., para. 214.

59 Prosecutor v. Milan Martić, supra note 56, para. 307; Prosecutor v. Mrkšić et al., supra note 56, para. 29 .

6 Prosecutor v. Tadić, 16 July 1999, ICTY, Appeal Judgment, IT-94-1-A, para. 351; Prosecutor v. Kupreškić et al., supra note 2, para. 549; Prosecutor v. Mrkšić et al., 13 September 1996, ICTY, Review of Indictment pursuant to Rule 61 of the Rules of Procedure and Evidence, IT-95-13-R61, para. 29; Prosecutor v. Galić, supra note 56, para. 143; Prosecutor v. Akayesu, supra note 56 , para. 575. Among commentators, Juan Soroeta Liceras, 'La protección de la persona humana en Derecho internacional', in Carlos Fernández de Casadevante Romaní (coord.), Derecho Internacional de los Derechos Humanos (Dilex, Madrid, 2003, 2nd ed.), p. 50; Paul Martens, 'L'humanité comme sujet du droit', in Thomas Berns (dir.), Le droit saisi par le collectif (Bruylant, Bruxelles, 2004), pp. 210-213. 
more illustrative to consider the need of protection of the victim in the event of defencelessness against an organized force, State-like or otherwise, and so, any person who is not part of such organized force will be deemed a civilian. ${ }^{61}$ Some have even argued that, in a situation of armed conflict and in the context of crimes against humanity, the customary notion of 'civilian population' encompasses enemy combatants. ${ }^{62}$ The ICTY supported this opinion in the Kupreškić case, as 'these rules may be held to possess a broader humanitarian scope and purpose than those prohibiting war crimes'.63 In this regard, it should also be noted that the definition of crimes against humanity in the amended version of the International Military Tribunal for the Far East (IMTFE) was sufficiently broad to include military staff among their victims. So, while Article 6(c) of the Charter of the IMTN deemed murder, extermination, slavery, deportation and other inhuman acts 'committed against any civilian population' as criminal, all reference to the commission against a civilian population was removed in Article 5 (c) of the Charter of the ImTFE. ${ }^{64}$

All the above makes clear that, regarding crimes against humanity, the IHL notion of 'civilian population' is insufficient. Up to now, the term has been used to cover any possible situation where I HL grants protection to individuals, and beyond, as far as enemy combatants may also be part of the civilian population. Even if it helps invaluably in its definition, this a priori clear criterion is nonetheless only partially helpful when it comes to determining when a population is civilian, for several reasons. First, in times of armed conflict, the protection granted by the rule banning crimes against humanity would actually

61 Werle, supra note 39, p. 222; Ambos and Wirth, supra note 40, p. 22.

62 Antonio Cassese, International Criminal Law (Oxford University Press, Oxford, 2013, $3^{\text {rd }}$ ed.), p. 91; $c f$. Schwelb, supra note 39 , p. 190, at least regarding the crime against humanity of persecution. Others do not support this approach, e.g., André Huet and Renée Koering-Joulin, Droit pénal international (PUF, Paris, 1994), p. 105; Alicia Gil Gil, Derecho penal internacional. Especial consideración del delito de genocidio (Tecnos, Madrid, 1999), p. 115; Mirko Bagaric and John Morss, 'In Search of Coherent Jurisprudence for International Criminal Law: Correlating Universal Human Responsibilities with Universal Human Rights', 29(2) Suffolk Transnational Law Review (2006) 179 (referring in general to 'enemy service personnel').

63 Prosecutor v. Kupreškić et al., supra note 2, para. 547. Such an interpretation was also admitted by the French Cassation Court in the Barbie case (see Jean-Olivier Viout, 'The Klaus Barbie Trial and Crimes against humanity', 3 Hofstra Law and Policy Symposium (1999), 164-165).

64 Amended version available at Solis Horwitz, 'The Tokyo Trial', 28 International Conciliation (1950) 484. 
be broader than the one granted by I HL ${ }^{65}$ as far as the former would also cover enemy combatants. Second, the uncertainties surrounding the definition of 'civilian population' according to IHL, particularly in non-international armed conflicts, are imported to the determination of crimes against humanity. Third, and more importantly, to the extent that crimes against humanity can be committed both at war and in peacetime, the identification of civilians in accordance with IHL only is clearly too narrow. ${ }^{66}$

In this context, it is somehow shocking to see that judges at the ICC still resort to the IHL definition of civilian, as opposed to members of armed forces and other legitimate combatants. ${ }^{67}$ Both in Katanga and Bemba the Trial Chambers have relied on Article 50 of API to define 'civilian population,', 68 arguing that the definition therein is 'customary in nature and therefore relevant to the consideration of crimes against humanity. ${ }^{69}$ Compared to the general trend to broadly address the civilian status of those targeted by the typical attack in crimes against humanity, the ICC approach is a setback, as it relies on IHL standards to determine whether a population is civilian, particularly when the attack is directed against a population including both civilians and non-civilians. The Trial Chamber in Bemba deemed that, in such scenario, factors relevant to determining whether an attack was directed against a civilian population are:

the means and methods used in the course of the attack, the status of the victims, their number, the discriminatory nature of the attack, the nature of the crimes committed in its course, the form of resistance to the assailants at the time of the attack, and the extent to which the

65 See Rodney Dixon (rev. by Cristopher K. Hall), 'Crimes agains Humanity: Chapeau', in Otto Triffterer (ed.), Commentary on the Rome Statute of the International Criminal Court (C.H.Beck/Hart/Nomos, München/Oxford/Baden-Baden, 2008, 2 ${ }^{\text {nd }}$ ed.), marg. no.13, p. 181.

66 Werle, supra note 39, p. 222; Bollo Arocena, supra note 39, p. 98; Fenrick, supra note 46, p. 86.

67 The Prosecutor v.Jean-Pierre Bemba Gombo, 15 June 2009, ICC, Decision Pursuant to Article 61 (7)(a) and (b) of the Rome Statute on the Charges of the Prosecutor Against Jean-Pierre Bemba Gombo, ICC-01/05-01/08, paras. 77-78; Situation in Côte d'voire, 3 October 2011, ICC, Decision Pursuant to Article 15 of the Rome Statute on the Authorisation of an Investigation into the Situation in the Republic of Côte d'Ivoire, ICC-02/11, para. 33; Prosecutor v. Germain Katanga, supra note 1, para. 1102.

68 The Prosecutor v. Jean-Pierre Bemba Gombo, supra note 38 , para. $15^{2}$.

69 Ibid. 
attacking force complied with the precautionary requirements of the laws of war. ${ }^{70}$

As a result, this interpretation of the term can only work when crimes against and Bemba. Instead, the IHL definition of 'civilian population' cannot be easily translated to crimes against humanity committed in peacetime. In fact, the unsuitability of IHL standards to determine the civilian population when crimes against humanity are committed in peacetime has led the ICC to interpret this term it in a completely different way, based on discrimination, as we will discuss in the next section. armed conflict and peace makes the ILH distinction between combatants and civilians -or between combatants and non-combatants- unsatisfactory when applied to crimes against humanity in contexts other than armed conflicts. In times of peace, when no armed force is involved, such a distinction lacks any sense. This is also true for internal disturbances and tensions that do not amount to a NIAC, even if the government is compelled to resort to police forces or armed units to restore order. ${ }^{71}$ In fact, international tribunals dealing with situations encompassing other than armed conflicts, just like the International Criminal Tribunal for Rwanda (ICTR) and the ICC, have put forward alternative criteria to determine who is a civilian.

The parameter introduced by the ICTR, applicable independently of armed conflicts, considers that the notion of 'civilian population' excludes personnel in charge of maintaining public order and endowed with lawful means to exercise the use of force, as police officers or members of national police. ${ }^{72}$ Commentators are divided with regard to the felicity of this interpretation. Some deem it as more restrictive than that in a situation of armed conflict. ${ }^{73}$ On the contrary, those supporting this criterion believe that what is relevant is that they use their power against the civilian population on behalf of the

\footnotetext{
$70 \quad$ Ibid., para. 153 .

71 Comité International de la Croix-Rouge, supra note 30, para. 4341, pp. 1343-1344.

72 Prosecutor v. Kayishema \& Ruzindana, 21 May 1999, ICTR, Trial Judgment, ICTR-95-1-T, para. 127 .

73 Simon Chesterman, 'An Altogether Different Order: Defining the Elements of Crimes against Humanity', 10(2) Duke Journal of Comparative and International Law (2000) 322.
} 
State apparatus or that of the organized group holding the de facto authority, ${ }^{74}$ which is consistent with an interpretation of the term civilian different from the one provided by IHL and adapted to the raison d'être of crimes against humanity.

The ICC case-law provides with another criterion. Although (as already mentioned $)^{75}$ most of the time the ICC follows the traditional IHL approach to 'civilian population', it has re-interpreted its scope when it comes to contexts of post-electoral violence (Kenya and Côte d'Ivoire), where it identifies the civilian population by a 'distinguishable group'. Such an approach is not completely new, though. In the Nikolic case, the ICTY stated that one of the components of the requirement that crimes must be directed against any civilian population was that 'the crimes must be directed at a civilian population, specifically identified as a group by the perpetrators of these acts' ${ }^{76}$ Furthermore, it must be noted that group affiliation has also been considered one of the several factors that should be weighed when assessing whether an attack has been directed against a civilian population. In Kunarac, the ICTY indicated that:

In order to determine whether the attack may be said to have been [directed against a civilian population], the Trial Chamber will consider, inter alia, the means and method used in the course of the attack, the status of the victims, their number, the discriminatory nature of the attack, the nature of the crimes committed in its course, the resistance to the assailants at the time and the extent to which the attacking force may be said to have complied or attempted to comply with the precautionary requirements of the laws of war (emphasis added). ${ }^{77}$

The ICC used it for the first time in 2010, regarding the situation in Kenya. In its decision on the authorization of an investigation, the ICc Pre-Trial Chamber II stated that the potential civilian victims of a crime under article 7 of the Statute are groups distinguished by nationality, ethnicity or other distinguishing features' (emphasis added). ${ }^{78}$ Besides, it specified that the term 'civilian

74 Werle, supra note 39, p. 223; see also María Torres Pérez, La responsabilidad internacional del individuo por la comisión de crímenes de lesa humanidad (Tirant lo Blanch, Valencia, 2008), p. 127.

75 See supra Section 3.

76 See also Prosecutor v. Nikolić, 20 October 1995, ICTY, Review of Indictment pursuant to Rule 61 of the Rules of Procedure and Evidence, IT-94-2-R61, para. 26. Emphasis added.

77 Prosecutor v. Kunarac et al., supra note 1, para. 91.

78 Situation in the Republic of Kenya, 31 March 2010, ICC, Decision Pursuant to Article 15 of the Rome Statute on the Authorization of an Investigation into the Situation in the Republic of Kenya, ICC-01/o9, para. 81. 
population' 'refers to persons who are civilians as opposed to members of armed forces and other legitimate combatants. ${ }^{\prime}{ }^{9}$ Although it further relied on the discriminatory nature of the attack to determine whether it had been directed against a civilian population, ${ }^{80}$ the statement above-reproduced goes far beyond the potential evidences to be weighed when assessing the civilian nature of the target of the attack. On the contrary, it rather introduces an additional delimitation of the condition of civilian, which will not only be established by the status of the victims (non-combatants - or non-member of public order forces, in the ICTR approach -) but also by their affiliation to a distinguishable group, these two conditions seemingly being cumulative rather than alternative.

This jurisprudential turn seems to be a misinterpretation of previous ICC case-law on the scope of the reference to any civilian population. This can be inferred from the fact that, in its support, the Chamber in Kenya cites the decisions on the confirmation of charges in the Bemba and the Katanga cases, where such a requirement cannot be found. Instead, they clearly say that 'the term 'civilian population' within the meaning of article 7 of the Statute affords rights and protections to 'any civilian population' regardless of their nationality, ethnicity or other distinguishing feature'. ${ }^{81}$ As it becomes obvious, these words express the contrary of the interpretation given by the Chamber in Kenya. But even if one could contend that we are before a distortion of the criterion resulting from a misreading, its reiteration in subsequent decisions regarding not only the situation in Kenya, but also in Côte d'Ivoire, ${ }^{82}$ supports the conclusion that the ICC considers it a proper way to determine the civilian nature of a population in times of peace.

\section{Ibid.}

8o Ibid., para. 108: 'in making its assessment whether the attacks were directed against a civilian population, the Chamber takes into account the information relevant to the status of the victims, their ethnic or political affiliation as well as the methods used during the attacks'.

81 The Prosecutor v. Germain Katanga and Mathieu Ngudjolo Chui, 30 September 2008, ICC, Decision on the Confirmation of Charges, ICC-01/04-01/07, para. 399. This idea is later rephrased in The Prosecutor v. Jean-Pierre Bemba Gombo, supra note 67, para. 76 .

82 The Prosecutor v. William Samoei Ruto, Henry Kiprono Kosgey and Joshua Arap Sang, 23 January 2012, ICC, Decision on the Confirmation of Charges Pursuant to Article 61(7)(a) and (b) of the Rome Statute, ICC-01/o9-01/11, para. 164; The Prosecutor v. Francis Kirimi Muthaura, Uhuru Muigai Kenyatta and Mohammed Hussein Ali, 23 January 2012, ICC, Decision on the Confirmation of Charges Pursuant to Article 61(7)(a) and (b) of the Rome Statute, ICC-01/o9-02/11, para. 110; The Prosecutor v. Laurent Gbagbo, 12 June 2014, ICC, Decision on the confirmation of charges against Laurent Gbagbo, ICC-02/11-01/11, para. 209. 
This approach, however, is not devoid of disadvantages. The relevance given by the ICC to membership to a group with a certain identity is troublesome to the extent that it incorporates discrimination against a group as one of the prerequisites of the actus reus of the general chapeau. Nonetheless, discrimination is not an element therein according to customary international law, ${ }^{83}$ but only of the crime against humanity of persecution specifically, where the discriminatory intent is a legal component of the crime, and discrimination is also required in the actus reus. ${ }^{84}$

The exclusion of discrimination (and generally of motives) from Article 7 ICC Statute results from the evolution of the customary definition of crimes against humanity. ${ }^{85}$ Until the mid-8os, the prevailing opinion was that crimes against humanity were characterized by a special intention of attacking a person precisely for such affiliation. ${ }^{86}$ From this perspective, the victim of crimes against humanity was a certain human group, identified by virtue of criteria such as race, religion or nationality. ${ }^{87}$ On the contrary, the most modern configuration of the category makes clear that any person can be a victim of crimes against humanity, not forgetting that protection is afforded for belonging to the civilian population, ${ }^{88}$ understood in a broad sense.

Notwithstanding the above, the matter of whether or not a discriminatory intent should be required in crimes against humanity was not settled

83 Prosecutor v. Kupreškić et al., supra note 2, para. 558; Prosecutor v. Akayesu, supra note 56, para. 568; Attorney-General of the Government of Israel v. Adolf Eichmann, 12 December 1961, District Court of Jerusalem, in 36 International Law Reports (1968) 41.

84 Prosecutor v. Tadić, supra note 38, para. 694; Prosecutor v. Kordić \& Čerkez, 26 February 2001, ICTY, Trial Judgment, IT-95-14/2-T, para. 189; Prosecutor v. Kvočka et al., 2 February 2001, ICTY, Trial Judgment, IT-98-30/1-T, para. 184; Prosecutor v. Krnojelac, 15 March 2002, ICTY, Trial Judgment, IT-97-25-T, para. 431; Prosecutor v. Naletilić \& Martinović, 31 March 2003, ICTY, Trial Judgment, IT-98-34-T, para. 634.

85 Darryl Robinson, 'Defining 'Crimes against Humanity' at the Rome Conference', 93(1) American Journal of International Law (1999) 46-47.

86 See International Law Commission, Second report on the draft code of offences against the peace and security of mankind, by. Mr. Doudou Thiam, Special Rapporteur (A/CN.4/377 \& Corr.1), para. 32; Report of the International Law Commission on the Work of its 38 th Session, 5 May-11 July 1986 (A/41/10), para. 88. See also Rosa Ana Alija Fernández, La persecución como crimen contra la humanidad (Publicacions UB, Barcelona, 2011), pp. 144-146.

87 See e.g., Gil Gil, supra note 62, pp. 115-116 and 124-127; Meyrowitz, supra note 39, p. 276; Morris and Scharf, supra note 38, p. 81 .

88 Claire De Than and Edwin Shorts, International Criminal Law and Human Rights (Sweet \& Maxwell, London, 2003), p. 92. 
until recently. ${ }^{89}$ In fact, Article 3 ICTR Statute called for an attack launched 'against any civilian population on national, political, ethnic, racial or religious grounds. ${ }^{90}$ Meanwhile, the ICTY opted in Tadic for requiring it in order to appreciate the commission of crimes against humanity, taking into account the report of the Secretary-General ${ }^{91}$ and the remarks of some States members of the Security Council made after the approval of resolution 827 (1993) 92 Despite this decision, the Trial Chamber was aware that this requirement was not necessary by virtue of customary international law. ${ }^{93}$ Later, the Appeals Chamber corrected this criterion when affirming that the discriminatory intent was not part of the elements of crimes against humanity with the exception of the crime against humanity of persecution. ${ }^{94}$

Things being so, the requirement for victims to belong to a group can only be taken as an indication that the attack has been directed against a collective target that presumably constitutes a civilian population. Instead, it cannot be deemed a defining - and reducing - criterion of the notion of 'civilian population'. Therefore, the parties should not be expected to prove such group affiliation, as that would increase disproportionately the evidence threshold, when belonging to a civilian population has always been interpreted in a broad sense.

As we concluded above, the element of the civilian population in crimes against humanity committed in an armed conflict is understood as an accumulation of a broad range of situations where I $\mathrm{HL}$ grants protection. Out of an armed conflict, though, the term 'civilian population' loses its sense, as - in the absence of combatants - everybody is a civilian. This ascertainment explains

89 On the uncertainties on this at the preparatory works of the ICc State, see Dixon, supra note 65 , margin n. 3, p. 168.

9o Emphasis added.

91 Secretary-General, Report of the Secretary-General pursuant to paragraph 2 of Security Council Resolution 808 (1993) (S/25704), para. 48.

92 Security Council, Provisional Verbatim Record of the 3217th Meeting, Held at Headquarters, New York, on Tuesday, 25 May 1993 (s/PV.3217), p. 11 (statement by the representative of France), 16 (statement by the representative of the USA) and 45 (statement by the representative of the Russian Federation).

93 Prosecutor v. Tadić, supra note 38, para. 650-652; Prosecutor v. Kunarac et al., supra note 1, para. 357. Requiring proving that element as well would have been a strategy to make the Appeals Chamber consider the issue and hence clarify it (Olivia Swaak-Goldman, 'The Crime of Persecution in International Criminal Law', 11(1) Leiden Journal of International Law (1998) 151).

94 Prosecutor v. Tadić, supra note 6o, paras. 283-305. See also Prosecutor v. Blaskić, supra note 55 , para. 260. 
the attempt of the ICC to give sense to the term by distinguishing between groups, which is problematic as far as it introduces discrimination as an element of the general chapeau. Therefore, a different criterion must be found, where the civilian population can be determined while granting it the broadest protection. To that extent, the analogy proposed by the ICTR to distinguish between public forces members endowed with lawful means to exercise the use of force can be a much better starting point than the ICC requirement of a distinguishable group, as we will discuss in the next section.

\section{$4 \quad$ A Potential Solution? Determining the Civilian Population on the Basis of International Human Rights Law and General International Law on State Responsibility for Wrongful Acts}

As a result of the difficulties to comprehensively define the civilian population as an element of the general chapeau of crimes against humanity, some have given up trying. The ICTY, for instance, has pointed out that the specificity of crimes against humanity does not derive from whether the victims are civilians but rather from the scale and organization of the commission of those crimes. ${ }^{95}$ This approach is in consonance with the ground for incriminating the specific acts included in the category, given that its goal is to protect the individuals per se, by means of safeguarding their fundamental human rights. ${ }^{96}$ So, the fact that a person targeted by the attack is vested with a specific status in accordance with international law at the time of committing the crime has no significant effect on the categorization of such conduct as a crime against humanity. Quite the contrary, the particular circumstances in which the violations of human rights take place are much more significant. ${ }^{97} \mathrm{So}$, if the 'civilian population' element is not relevant to determine whether crimes against humanity have been committed, the question then is whether it should be suppressed as an element of the general chapeau. We believe, though, that there is a point in keeping it: to have enough elements in order to clearly establish in which circumstances the most serious crimes amounting to international crimes are committed. In any event, this element should be reformulated so as to have a single, comprehensive content, valid in all circumstances, and

95 Prosecutor v. Blaskić, supra note 55, para. 208.

96 Gil Gil, supra note 62, p. 124-125.

97 See Prosecutor v. Blaskić, supra note 55, para. 214; William Schabas, The UN International Criminal Tribunals. The Former Yugoslavia, Rwanda and Sierra Leone (Cambridge University Press, Cambridge, 2006), p. 191. 
consistent with the scope of the other elements and the spirit of the incrimination of crimes against humanity.

In doing so, several presumptions must be considered. The first one is the need to respect the principles stemming from Article 22(2) Icc Statute, namely: strict construction of crimes, prohibition of analogy, and interpretation of the definition of a crime in accordance with the in dubio pro reo principle. ${ }^{98}$ The second one is the rationale of crimes against humanity, namely, to ensure that certain serious violations of human rights are not granted impunity, particularly when they have been State-sponsored or committed by the de facto power over a territory, as it is assumed that otherwise, the State apparatus (or the political entity effectively controlling the territory) will pursue the repression of these behaviours. The third and last presumption is, as already mentioned, that crimes against humanity endanger fundamental human rights. ${ }^{99}$

If the standard of reference is the protection of fundamental human rights, one can wonder whether it is possible to define 'civilian population' in accordance with the rules governing this matter. Two potential criteria, both deriving from International human rights Law, can be suggested to determine what a civilian population is. The first one would delimitate it by focusing on those suffering from the attack, namely, the victims of human rights violations. The second one delimitates the term by focusing on those potentially launching the attack.

In the first criterion, a possible way to delimitate the civilian population would be to equate it to victims in a broad sense (at least including direct and indirect victims). ${ }^{100}$ But even if this is a tempting option, it does not solve the question of defining the notion of 'civilian population', to the extent that this would equate the target of the attack to the victims of the specific crimes against humanity. ${ }^{101}$ As a matter of fact, crimes against humanity are built on

98 See Mathias Holvoet, The State or Organisational Policy Requirement within the Definition of Crimes against Humanity in the Rome Statute: an Appraisal of the Emerging Jurisprudence and the Implementation Practice by ICc States Parties, ICD Brief 2, October 2013, p. 7, $<$ www.internationalcrimesdatabase.org/upload/documents/20131111T105507-ICD\%20 Brief\%20\%202\%20-\%2oHolvoet.pdf>, 23 September 2016.

99 See Alija Fernández, supra note 86, pp. 219-220, 225-231.

100 The notion of direct and indirect victims can be found, for instance, in the European Court of Human Rights case-law, as collected in its Admissibility Guide, p. 12, <www.dp-rs .si/fileadmin/dp.gov.si/pageuploads/RAZNO/Admissibility_guide_ENG.pdf >, 23 September 2016.

101 Cf. Göran Sluiter, "Chapeau Elements' of Crimes Against Humanity in the Jurisprudence of the UN Ad Hoc Tribunals', in Leila N. Sadat (ed.), Forging a Convention for Crimes against Humanity (Cambridge University Press, New York, 2011), p. 117. 
two levels: the context and the specific criminal conduct. The commission of one of the crimes encompassed by the category (e.g., homicide) is not per se an international crime, but it needs to be perpetrated in a certain context to increase the seriousness of such conduct to the extent that it constitutes a danger to international peace and security, and, accordingly, to merit an answer from international law. Hence, a homicide does not constitute a crime against humanity if not knowingly connected to a systematic or widespread attack against any civilian population. The contextual element, on the contrary, should be shaped independently of the existence of victims, and it is in this sphere that the definition of the notion of 'civilian population' as the target of the attack is relevant. Such notion presents a broad and diffuse nature that goes beyond the specific victims, although this should probably be modulated in light of the definition of attack provided by the ICC Statute, ${ }^{102}$ as it requires the multiple commission of acts referred in Article 7(1) ICC Statute. This ultimately implies the need to prove the existence of victims in order to establish whether an attack within the sense of crimes against humanity has been committed, thus leading to a circular argument. Likewise, if the civilian population is to include everyone whose fundamental human rights can be potentially violated, then all the population would be encompassed, given the universality of human rights, leading to another useless outcome of the definition of 'civilian population'.

Alternatively (second criterion), the term could be defined by the method of exclusion, based on the identification of those who can potentially raise State responsibility for breaches of fundamental human rights. The civilian population would then encompass everyone whose behaviour cannot entail international responsibility of the State. To the extent that International human rights Law grants protection to individuals from the arbitrariness and excesses of State power, the State will incur international responsibility for an internationally unlawful act if its agents and bodies, acting in such capacity (even ultra vires), ${ }^{103}$ fail to observe its obligations pursuant to international law be them treaty-based or derived from general international law (such as respecting fundamental human rights). Generally, this would result in excluding

102 According to Article 7(2)(a) Icc Statute, an attack is 'a course of conduct involving the multiple commission of acts referred to in paragraph 1 against any civilian population, pursuant to or in furtherance of a State or organizational policy to commit such attack'. Article 7 Draft Articles on Responsibility of States for Internationally Wrongful Acts (Draft RSIWA). Text of the draft articles available in International Law Commission, Report of the International Law Commission on the Work of its Fifty-third Session (23 April -1 June and 2 July-1o August 2001) (A/56/10), para. 76 . 
from the civilian population the State organs or agents launching the attack 692 and/or designing the policy underlying such attack. From this perspective, not 693 only the army or the police would be excluded from the civilian population, 694 but also other State bodies and agents empowered to exercise or order direct $\quad 695$ use of physical force, e.g., the government - as it is normally the one designing $\quad 696$ the policy underlying the attack -, or the civilian authorities in the local sphere $\quad 697$ who ordered the attack.

To determine the composition of the civilian population with reference to the general criteria of responsibility of the State for breach of international rules in the field of human rights would also permit to exclude from the notion of 'civilian population' those who discharge duties conferred by the State, ${ }^{104}$ bodies provided to a State by another State, ${ }^{105}$ or individuals acting under the direction or control of a State ${ }^{106}$ or acting in the absence of or by default of official authorities. ${ }^{107}$ The last two cases, in conjunction with the State responsibility for failing to take necessary measures to prevent the effects of the conduct of private parties, ${ }^{108}$ might also justify the exclusion of paramilitary groups from the civilian population. On the contrary, the members of foreign armed forces or insurrectional movements would belong to the civilian population irrespective of their status under $\mathrm{IHL}$, as admitted by international courts, ${ }^{109}$ inasmuch as they deserve the respect of their human rights acknowledged by international law - and specifically fundamental human rights - from the State under whose jurisdiction they are found. Likewise, this conception of civilian population would be perfectly valid for crimes against humanity committed in time of war by one party against its own population; a population that, as seen above, is almost irrelevant for IHL. ${ }^{110}$

Our proposal does not disregard the fact that crimes against humanity may be committed by organized groups, different from the State, as provided for by Article 7(2)(a) of the ICc Statute. In the earlier ICC case-law two different kinds of organizations were envisaged: either 'groups of persons who govern a spe-

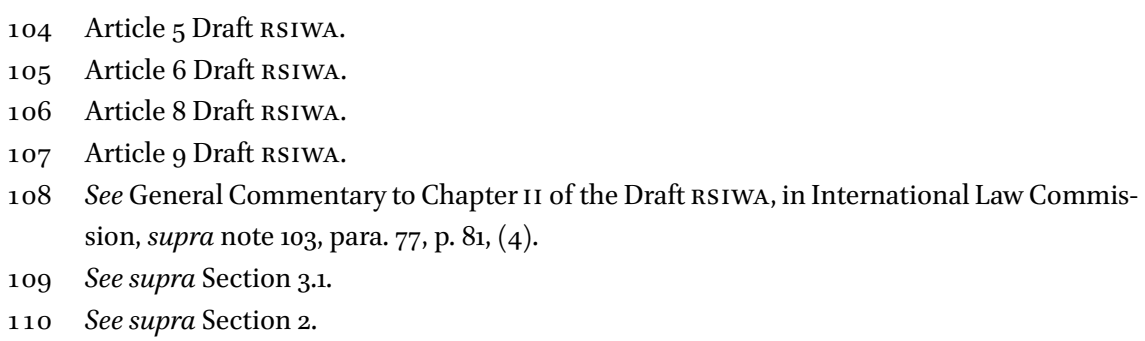


or systematic attack against a civilian population'.111 The first category would adjust to the traditional requirement of 'control' over the territory ${ }^{112}$ that excludes State responsibility over their acts, while the second one emphasizes the capability to launch an attack, in what seems to encompass any group with a certain structure and means to do so. Large as this criterion may seem, it is considerably reductive compared to the one put forward by Pre-Trial Chamber II in its decision authorizing the opening of an investigation into the situation in Kenya. There it stated that an organization could commit crimes against humanity insofar it was a group with 'the capability to perform acts which infringe on basic human values.'13 Further considerations to identify an organization in the sense of Article 7(2)(a) of the ICC Statute would be:

(i) whether the group is under a responsible command, or has an established hierarchy; (ii) whether the group possesses, in fact, the means to carry out a widespread or systematic attack against a civilian population; (iii) whether the group exercises control over part of the territory of a State; (iv) whether the group has criminal activities against the civilian population as a primary purpose; (v) whether the group articulates, explicitly or implicitly, an intention to attack a civilian population; (vi) whether the group is part of a larger group, which fulfills some or all of the abovementioned criteria. ${ }^{114}$

However, the Chamber insisted on the merely illustrative character of these considerations when determining whether a group qualifies as an organization under the ICC Statute. According to it, 'while these considerations may assist the Chamber in its determination, they do not constitute a rigid legal definition, and do not need to be exhaustively fulfilled'. ${ }^{15}$

Needless to insist on how vague - and therefore inappropriate to define an element of a crime - such requirement is, as anyone can infringe basic human values. The fact of acting alone or in group is only relevant insofar as, in theory, more people will do more harm than one person. But that argument cannot be

111 See e.g., The Prosecutor v. Germain Katanga and Mathieu Ngudjolo Chui, supra note 81, para. 396; The Prosecutor v. Jean-Pierre Bemba Gombo, supra note 67, para. 81.

112 As held by the United Nations, 'it is clear that the application of human rights standards to non-State actors is particularly relevant in situations where they exercise some degree of control over a given territory and population', see UN/UNHCR, International Legal Protection of Human Rights in Armed Conflicts (HR/PUB/11/01), p. 25.

113 Situation in the Republic of Kenya, supra note 78, para. 91.

114 Ibid., para. 93 .

115 Ibid. 
enough to turn a group into an organization in the sense of Article 7(2)(a) ICC Statute. In that case, who would make up the civilian population? The others, i.e., those who are not the ones launching the attack? And what if these ones are not a distinguishable group, but their only common feature is the purpose of attacking and infringing basic human rights? Where is the State left in this context? Is not it meant to prosecute and punish such acts? With such a vague delimitation of the organization, it is in no way surprising that the Chamber relied on discrimination to determine the civilian population, which is nonetheless equally inappropriate as well as insufficient. ${ }^{116}$

In our view, irrespective of who commits the crime, even if it is an organized non-State group, a crime against humanity will exist as long as it is launched against anyone who is not a de jure or de facto State agent (the latter including non-State actors who exercise some control over territory and people $\left.{ }^{117}\right)$, acting as such. Therefore, in areas out of reach of the State apparatus, those acting in substitution of State organs and agents should also be considered national agents, and not civilian population. By the same token, in territories under control of a non-State organization, those performing de facto State functions will be excluded from the civilian population. However, similarly to IHL, the presence of State officials (or analogous) among a mainly civilian population should not change the civilian nature of the population. Therefore, only if the attack is directed exclusively against acting members of police or armed forces, governmental officials or members of paramilitary groups (or analogous), will there not be a 'civilian population' in the sense of Article 7 ICC Statute. Also, when among the victims there are State agents off duty, e.g., neighbours of a village attacked by a non-State organized group, their civilian condition should be acknowledged. As a result of this approach, terrorist attacks and crimes committed by organized criminal groups would not a priori qualify as crimes against humanity either. ${ }^{118}$ In order to do so, some State involvement, either by

116 See supra Section 3.2.

117 See M. Cherif Bassiouni, Crimes Against Humanity in International Criminal Law (Kluwer Law International, The Hague, 1999, 2nd ed.), p. 245. In this regard, we agree with Judge Kaul, who has deemed that those organizations 'should partake of some characteristics of a State' that would eventually turn it 'into an entity which may act like a State or has quasi-State abilities' (Situation in the Republic of Kenya, supra note 78, Judge Kaul's dissenting opinion, para. $\left.5^{1}\right)$.

118 It should be kept in mind that terrorist attacks consisting of one single criminal event (e.g., 9/11) are not attacks in the sense of Article 7 ICC Statute (namely, a course of conduct). A literal interpretation of the authentic texts in Spanish and French is enough to reach this conclusion. A terrorist attack is translated for 'atentado terrorista' in Spanish and 'attentat terroriste' in French, while both versions of the ICC Statute refer to attack 
action or by omission, or a certain control by the terrorist group over the territory, would be required. ${ }^{119}$

In short, this would lead to a contrasting criterion similar to the current combatant/non-combatant dichotomy, but based on International human rights law combined with customary international law on State responsibility for wrongful acts instead of $\mathrm{IHL}$, as the rationale would be protection against State (or State-like organizations) arbitrariness rather than protection in times of armed conflict. This criterion - which does not require a pre-determination of individual responsibility, but remains at the factual level - would also usually allow a coherent determination of State responsibility for crimes against humanity when required.

\section{$5 \quad$ Conclusions}

The reference to 'any civilian population' as an element of the general chapeau of crimes against humanity is a legacy from the IHL distinction between combatants and civilians, as a result of the connection with crimes against peace and/or war crimes originally required by Article 6 of the Charter of the IMTN. Although such connection was abandoned at a very early stage in the customary configuration of crimes against humanity, the requirement of the attack being against 'any civilian population' remained. In quest of an independent meaning of 'civilian population' in crimes against humanity, the term has progressively separated from the civilian population of IHL and war crimes, although in an inconsistent way. This results in the absurdity of 'civilian population' having different meanings depending on whether crimes against humanity are committed in times of war or in times of peace.

The ICC case-law provides with a clear example of such a duality: in armed conflicts, 'civilian population' as an element of the general chapeau of crimes against humanity includes those who are not members of armed forces and other legitimate combatants, while in times of peace it is equated to a distinguishable group. However, in times of war, the customary norm resulting from the evolution of crimes against humanity as applied by the ad hoc Tribunals

('ataque' and 'attaque', respectively). Regarding organized criminal groups, one of the features of organized crime is its search for influence at the political, administrative and judicial level.

119 As stated in note 6 of the Elements of Crimes, the State or the organization can be exceptionally involved in the commission of crimes against humanity 'by a deliberate failure to take action, which is consciously aimed at encouraging such attack'. 
seems to assimilate the civilian population to non-combatants, namely, civilians and any former combatant (e.g., POW). This is particularly right in international armed conflicts; in NIAC, while the same principle would apply, it becomes harder to make a distinction between civilians and combatants, especially in unstructured conflicts. In both cases, a 'pure' combatant (i.e., a combatant in combat) could just clearly be a victim of certain war crimes such as perfidy or use of forbidden weapons. Instead, international tribunals have included enemy combatants among the civilian population, and they can therefore be victims of any crime against humanity. Hence, in wartime the prohibition of crimes against humanity affords protection to a larger number of persons than IHL.

In times of peace, on the contrary, the distinction between civilians and combatants lacks any sense. In the absence of combats, the whole population is civilian, so the term becomes empty of content. Consequently, international tribunals have attempted to provide the notion of 'civilian population' with some specific meaning, either by substituting combatants for public officers endowed with lawful means to exercise the use of force (ICTR), or by equating it to a distinguishable group (ICC). In our opinion, the ICTR position offers an interesting analogy to the dichotomy combatant/non-combatant and can be a good starting point for a comprehensive definition of 'civilian population'. Instead, the ICC approach deserves criticism, inasmuch it introduces discrimination as an element of the general chapeau of crimes against humanity, despite motives having been excluded from the customary definition of the category (discrimination is restricted to the specific crime against humanity of persecution).

A single definition of civilian population for crimes against humanity, operative in times of both war and peace, is therefore needed. Since crimes against humanity consist in violations of fundamental human rights, we believe that the criterion to define 'civilian population' therein should always be based on international law of human rights, which follows no other criterion than general international law's one. A civilian population would thus be any individuals that are not, de jure or de facto, State agents acting as such. The target of the attack would then be defined in a negative way, as anyone not performing State functions in the instant case, irrespective of the nature or condition of the perpetrator, who would usually be (but not necessarily) a State agent. Such single definition would be valid for any crime against humanity, committed in times of peace or in times of war, be it international or non-international, and would be clearly distinct - at least univocal - from the civilian population referred to in war crimes. 